\title{
Monoclonal Antibodies Made to Chick Mesencephalic Neural Crest Cells and to Ciliary Ganglion Neurons Identify a Common Antigen on the Neurons and a Neural Crest Subpopulation
}

\author{
K.F. Barald \\ Department of Anatomy and Cell Biology, Program in Neuroscience, and Program in Cell and Molecular \\ Biology, University of Michigan Medical School, Ann Arbor
}

We previously reported the production of monoclonal antibodies (Mabs) that identified cell surface components of cultured chick and quail ciliary ganglion (CG) neurons and of a subpopulation of neural crest (NC) cells from 31-hr chick embryos (stage 9). Here we demonstrate that another Mab, CG-14, which was prepared to nitrocellulose-immobilized, lightly fixed (0.125\% paraformaldehyde) mesencephalic $\mathrm{NC}$ cells from 31-hr (stage 9) chick embryos, labels the same antigen(s) recognized by CG-1 and CG-4 on both the CG neurons and the subpopulation of NC cells. All three Mabs label a polypeptide of $75 \mathrm{kD}$ on Western blots of one-dimensional SDS-polyacrylamide gels. CG-14 blocked the binding of CG-1 and/or CG-4 to the $75 \mathrm{kD}$ band on Western blots and blocked the binding of CG-1 and CG-4 to CG and NC cells. CG-1 and/or CG-4 antibodies, in turn, blocked the binding of CG-14 to Western blots, as well as NC and CG cells. We had previously shown that antibodies CG-1 and CG-4 were synergistically cytotoxic for the majority $(95 \%)$ of cultured CG neurons in vitro in the presence of guinea pig complement. Here we show that the antibodies, which are both of the $\gamma_{2 \mathrm{a}}$ subclass, are also cytotoxic for the NC cells that they label in vitro. After the cells are ablated in culture, no other cells bearing the antigen(s) recognized by any of the three Mabs appear over a 2.5-week period. CG-14, however, is not cytotoxic for either the CG or NC cell populations alone or in combinations with CG-1 or CG-4.

These results confirm our original observation that cultured CG neurons and NC cells share cell-surface antigen(s). The antigen recognized by all three Mabs appears to be the same whether the immunogen used to produce the antibodies was CG neurons or NC cells. This finding encourages us to continue tests of the hypothesis that the subpopulation of mesence- phalic neural crest cells contributes to the formation of the ciliary ganglion in the embryo. Further characterization of the antigen appears in the accompanying paper.

Key words: complement-mediated cytotoxicity, Western blots, neuronal development, cell lineage

\section{INTRODUCTION}

The neural crest provides an excellent model system for the study of segregation of cellular functions during neuronal development. It arises transiently during early development and provides nearly all of the neurons of the peripheral nervous system (PNS), as well as a myriad of other cell types (for reviews, see LeDouarin, 1983, 1986a,b; LeDouarin et al., 1985; Weston, 1983; Weston et al., 1988). One objective of our work has been to test the possibility that certain cell surface and other functional characteristics of crest-derived neuronal subpopulations are established early in development, well before neuronal morphologies are expressed and before crest cell migration begins (Barald, 1982; Barald and Wessells, 1984).

Such subpopulations might become determined at specific times in development (Le Douarin, 1986a,b; Weston et al., 1988), and at such times their developmental repertoires may be at least partially limited (Weston et al., 1988). We are also interested in discovering which cellular properties are intrinsic and which are under environmental (epigenetic) control. To identify

Received June 6, 1988; revised June 13, 1988; accepted June 23, 1988.

Address reprint requests to Kate F. Barald, Department of Anatomy and Cell Biology, University of Michigan Medical School, Ann Arbor, MI 48109-0616. 
neural crest-derived neuronal subpopulations and follow them throughout development, we have employed monoclonal antibodies (Mabs) as cell surface markers.

At the time we reported the first Mabs that labeled neural crest subpopulations (Barald, 1982), it was still the general belief that most, if not all, neural crest (NC) cells were pluripotent and that the premigratory crest was relatively homogeneous (LeDouarin et al., 1978; SieberBlum and Cohen, 1980). The identification of neural crest subpopulations with Mabs was among the first demonstrations that some populations of NC cells might be determined very early in development (Barald, 1981, 1982, 1987; Barald and Wessells, 1984). Subsequently, other investigators have used Mabs to identify additional subpopulations of NC cells prior to or very early in crest migration (Ciment and Weston, 1982, 1985; Vincent et al., 1983; Marusich et al., 1986; Barbu et al., 1986; Ziller et al., 1987; Weston et al., 1988). Some of these monoclonal antibodies recognize crest subpopulations that also appear to be neurogenic precursors (Ziller et al., 1987; Weston et al., 1988).

Some NC cells may remain "pluripotent" (Anderson et al., 1985; Anderson and Axel, 1986) or may remain plastic in their developmental repertoire longer than others during embryonic development (Weston et al., 1988). However, there is now a great deal of support for the hypothesis that very early segregation of subpopulations of neural crest precursors, some of which are neurogenic, occurs in the avian neural crest (Barald, 1981, 1982, 1987; Barald and Wessells, 1984; LeDouarin, 1986a,b; Ziller et al., 1987; Weston et al., 1988).

The ciliary ganglion of the embryonic chick is a parasympathetic ganglion that arises from the mesencephalic (and anterior rhombencephalic) neural crest (Narayanan and Narayanan, 1978; Noden, 1978; LeDouarin et al., 1978). The ganglion contains two populations of neuronal cells, both of which are cholinergic (Landmesser and Pilar, 1972; Nishi and Berg, 1977, 1981a,b). The two populations of ciliary ganglion (CG) neurons innervate unique targets: The ciliary neurons make contact with the ciliary body and the striated muscle of the iris; choroid neurons make synapses on the smooth muscle of the vasculature of the choroid layer.

Our antibody studies have been directed at the molecular and functional characterization of cell surface antigen(s) shared by CG and NC cells (Barald, 1981, 1982) and at determining whether the antigen-positive mesencephalic NC cells are potential precursors of either of the two ciliary ganglion neuronal populations. We have found that a subpopulation of NC cells, which may be neurogenic precursors of the ciliary and/or choroid neurons, can be identified early in development, before neuronal phenotypes are expressed and, in fact, before the crest cells begin to migrate. In this report, the Mabs
CG-1 and CG-4, which were made to CG neurons, and CG-14, which was made to NC cells, are shown, through binding and blocking studies, to label common antigen(s) on CG neurons and NC cells.

\section{MATERIALS AND METHODS}

\section{Birds}

Fertile White Leghorn chick eggs were obtained from Omega Chicks (East Lansing, MI), Bilbie's Poultry Farm (Ann Arbor, MI), or the Poultry Science Department of Michigan State University (East Lansing, MI) and were maintained in a force-draft incubator at 38$39^{\circ} \mathrm{C}$ for $28 \mathrm{hr}$ to 17 days. Embryos were staged according to Hamburger and Hamilton (1951), and throughout this report, when stages are indicated, the Hamburger and Hamilton staging is used.

\section{Preparation of Cell Cultures}

Cultures of CG neurons were prepared by our previously published procedures (Barald and Berg, 1979; Barald, 1982; Barald and Wessells, 1984). Briefly, 8-day chick or quail embryos were decapitated and the optic nerve exposed by making a cut along the orbit through the skin and cartilage and rolling the eye forward. The ganglion was plucked from its position at the base of the optic nerve with a pair of number 5 (Inox) forceps. Sixty ganglia were obtained from 30 embryonic chicks; the cells were dissociated in $0.25 \%$ trypsin (Gibco, Grand Island, NY) in calcium- and magnesium-free modified Puck's saline containing 1\% glucose (MPG) (Barald and Berg, 1979). Medium containing $10 \%$ chicken serum or $10 \%$ horse serum (HS) was added to the trypsinization mixture to stop the reaction; the individual cells were collected by centrifugation at $500 \mathrm{~g}$ on an IEC table top centrifuge at room temperature. One to six ganglion equivalents (1.2-7.2 $\times 10^{4}$ cells) were plated on collagen or polyornithine substrates (Barald and Berg, 1979b) in each 35-mm tissue culture dish. Addition of affinitypurified antibodies and/or complement (see below) was made directly to the medium when antibody effects were studied. All cultures were grown in a humidified incubator in air with $5 \% \mathrm{CO}_{2}$ at $37^{\circ} \mathrm{C}$.

\section{Culture Media}

The CG cultures were grown in Medium F12 (Gibco), with 50 units $/ \mathrm{ml}$ penicillin, $50 \mu \mathrm{g} / \mathrm{ml}$ streptomycin, $10 \mathrm{mM}$ glutamine (Gibco), 10\% (v/v) chicken serum or $10 \%(\mathrm{v} / \mathrm{v})$ horse serum (Gibco), and $5 \%(\mathrm{v} / \mathrm{v})$ chick embryo extract (CEE) prepared as previously described (Barald and Berg, 1979) or $10 \mu \mathrm{g} / \mathrm{ml}$ ovotransferrin (conalbumin; Sigma, St. Louis, MO). Because early experiments comparing chick and horse serum showed that chicken serum was consistently better at support of both these cultures and NC cultures, chicken serum (CS) (obtained from Omega Chicks) was used instead of horse 
serum in most cultures. Medium was also supplemented with pyruvate $\left(1.0 \times 10^{-3} \mathrm{M}\right)$, serine $\left(2 \times 10^{-4} \mathrm{M}\right)$, iron $\left(2.5 \times 10^{-7} \mathrm{M}\right)$, and insulin $\left(8.3 \times 10^{-7} \mathrm{M}\right)$ (Skaper et al., 1984).

Neural crest cells were grown in this medium supplemented with $10 \%$ chicken serum or $15 \%$ fetal bovine serum (FBS) (see also, Ziller et al., 1987). Either medium was supplemented with various tissue-conditioned media added at $10-50 \%$ concentration in some cases.

\section{Tissue-Conditioned Media}

Eye extract (10\%) was prepared according to Nishi and Berg (1981a,b). Iris-conditioned medium (ICM) was made by plating iris cells from 17-day embryonic chick in FBS or CS containing-medium made as described above. Lenses were removed from isolated eyes, and 15 iris with the attached ciliary body were cut into small pieces and then triturated to produce individual cells or small cell clumps. These cells were cultured in medium containing the appropriate serum for up to 2 weeks. Medium was changed every 3 days.

\section{Heart-Conditioned Media}

Some CG and NC cultures were also grown in 50\% heart-conditioned medium (HCM) (Nishi and Berg, 1977; Barald and Berg, 1979). Heart-conditioned medium (HCM) was made by plating eight embryonic 8-day dissociated hearts in 125-mm culture bottles (Costar) in 10\% chicken serum or $15 \%$ FBS, $5 \%$ CEE (or $10 \mu \mathrm{g} / \mathrm{ml}$ ovotransferrin), and $10 \mathrm{mM}$ glutamine in Medium F12 supplemented as described above. After 3 days the medium was collected, and fresh medium was added to the heart cells. The HCM from several cultures was pooled and filtered. It was used within 2 days.

\section{Cell Counts}

CG neurons were counted in 15 fields of view per culture at $\times 200$ magnification for binding and cytotoxicity studies. These fields were spaced by using a specific set of predetermined coordinates set with the stage micrometers of a Leitz Diavert Phase/Florescence or a Diavert fixed stage Phase/Smith interference contrast optics microscope so that random, evenly spaced fields of view were counted. The area examined was $3.3 \%$ of the total surface area (as described by Nishi and Berg, 1981b). CG neurons were phase-bright, with neurites extending several cell diameters. NC cells in culture had a stellate morphology. NC cells positive for Mab staining were identified by counting all cells in a culture dish examined with epifluorescence optics as described below. "Neuron-like" cells in NC cultures were round, phase-bright cells either with short neurite-like processes or with neurite-like processes extending many cell diameters.

\section{Preparation of Neural Crest Cultures}

Cranial neural crest cultures from 31-hr, stage 9 (Hamburger and Hamilton, 1951), seven-somite chick embryos were prepared as previously described (Barald, 1982; Barald and Wessells, 1984). Cultures were 1) analyzed for immunofluorescence by light microscopy before or after subculturing as previously described (Barald, $1982)$; 2) used for immunoablation experiments with antibodies and complement (see below); and 3) injected or implanted into mice on nitrocellulose paper for the production of Mabs (see below; Barald and Wolff, manuscript in preparation).

\section{Preparation of NC Cells on Nitrocellulose Filters for Implantation or Injection Into Mice for the Preparation of Mabs}

NC cells from 31-hr embryos were prepared as whole explants of mesencephalic NC (Smith et al., 1979; Barald, 1982) or were plated with neural tubes, which were later removed. Cells were grown on Millicell-HA sterile filter culture plate inserts $(0.45 \mu \mathrm{m}$ pore size; 12 $\mathrm{mm}$ diameter). The inserts were placed in the wells of Costar 24-well culture plates maintained in humidified chambers $(150-\mathrm{mm}$ petrie dishes lined with distilled water-soaked kimwipes). Excised neural crests were placed on the medium-wetted filter paper and left for 4$7 \mathrm{hr}$ for cell attachment to take place prior to addition of appropriate media (see above) which was added after attachment. The cells remained in culture for 12-24 hr and then were fixed in $0.125 \%$ paraformaldehyde, and the filters were cut from the plastic support for subcutaneous implantation in mice.

Implantation was accomplished by inserting either the whole filter or pieces of the filter beneath the back skin of the host (a 1.5-2-month-old BAlb/C mouse). If the whole filter was used, the animal was anesthetized i.p. with $12 \mu \mathrm{l} / \mathrm{gm}$ body weight of a $3.6 \% \mathrm{w} / \mathrm{v}$ solution of chloral hydrate in phosphate-buffered saline (PBS). A portion of the upper back between the shoulder blades was shaved and alcohol treated. An incision $1 \mathrm{~cm}$ long was made parallel to the long axis of the body and the skin gently teased from the mucosa. The nitrocellulose filter (12 $\mathrm{mm}$ in diameter) containing the cells was implanted cell side down and three sutures used to close the wound. If pieces of nitrocellulose filter were used, they were cut out of fixed-cell preparations. The pieces were cut small enough to fit into the beveled end of a 19-gage needle $(1 \times 5 \mathrm{~mm})$. The back of the anesthetized mouse was shaved, and a light layer of vaseline was rubbed into the skin. Mineral oil was drawn into the needle to lubricate it. The nitrocellulose piece was then dipped in Freund's incomplete adjuvant (Miles) or in mineral oil and slightly rolled with number 5 forceps (Inox) and between latex-gloved fingers until it could be fitted into 
the pointed end of the needle (not loaded from the luer end). Cells were on the inside of the rolled nitrocellulose piece, but the piece was small enough so that the roll did not double on itself.

The piece of nitrocellulose was then pushed gently into the mineral oil-lubricated syringe. A hole was made in the skin with another needle, which was also used to separate the skin from the mucosa. Then the nitrocellulose-loaded needle was slipped into the hole after the first needle was removed. The nitrocellulose-loaded needle (without a syringe) was positioned under the skin, and a longer needle of finer gage was inserted into the barrel from behind to push out the nitrocellulose piece. Once the piece of nitrocellulose with NC cells was beneath the skin, the piece unrolled and could easily be turned $90^{\circ}$ with fingers so that it did not come out of the hole. Excess Freund's or mineral oil was expressed from the hole, the back washed and dried, and the skin recoated with vaseline.

Immunization scheme. The day that cells on nitrocellulose were injected or implanted was designated day 1 in the immunization scheme. No other immunizations or boosts were necessary. However, if desired, at 3.5 weeks after the initial injection, an i.p. boost may be given. Fusion of the spleen cells, which were selected on mesencephalic NC antigen lawns (Barald and Wessells, 1984; Barald, 1987), followed 4 days later.

Screening of Mabs. Supernatants from the hybridomas were screened after 11-14 days in culture. They were screened with fluorescent second-step antibodies by epifluorescence microscopy either on mesencephalic neural crest cultures or CG neuron cultures, on cryostat sections of 31-hr to 3-day chick embryos, or on Western blots of ciliary ganglia or of neural crest cultures (Barald, 1982; Barald and Wessells, 1984). Supernatants were applied and visualized with second-step rabbit antimouse IgG and or IgM ( $\gamma$ - or $\mu$-chain specific) antibodies conjugated with fluorescein or rhodamine in the case of epifluorescence microscopy on cultures or sectioned embryos (Barald and Wolff, manuscript in preparation). Visualization was as in Barald (1982). For Western blots, the second-step antibody was conjugated with alkaline phosphatase or horseradish peroxidase (see below).

\section{Blocking Studies}

Blocking studies were conducted to determine the ability of various reagents to block binding of the specific Mabs and vice versa. CG neurons or NC cells in culture were pretreated with: 1) Mab CG-1, CG-4, or CG-14 with or without a second-step fluorescent antibody; 2) the second-step antibody alone as control; 3) $10^{-8} \mathrm{M} \alpha$ bungarotoxin (BTX); and 4) either an anti-acetylcholinesterase (AChE) antibody made in rabbits or a monoclonal anti-AChE (Barald, unpublished data). The cells were subsequently treated with CG-1, CG-4, or CG-14 followed by a second-step antibody conjugated with a different-colored fluorochrome.

\section{Western Blots}

Blots were prepared by the method of Towbin et al. (1979). Briefly, CG neurons or neural crest cultures were homogenized in SDS sample buffer and heated for $3 \mathrm{~min}$. Electrophoresis was carried out in SDS-mercaptoethanol-containing gels (Laemmli, 1970), and the proteins were transferred to nitrocellulose sheets with a Bio-Rad transblot apparatus $(80 \mathrm{v} / 1 \mathrm{hr})$ or a Genie electroblotter (RPI) (24 v/l hr) in TRIS-glycine (pH 8.3)/20\% methanol buffer. Temperature was controlled by ice bath immersion of the apparatus. After blotting, the nitrocellulose sheets were transferred to and clamped in an immunoblotter (Miniblotter), which could be used to test 52 supernatants at once. Each well holds $70-80 \mu$ lof sample. After blocking $30 \mathrm{~min}$ in a saturated, filtered solution of "blotto" (Carnation Instant Milk Powder in phosphatebuffered saline $/ 0.5 \%$ Tween 20 ) and rinsing twice in distilled water (DW), the blots were incubated in the hybridoma supernatants (undiluted, and diluted $1 / 2$ and $1 / 10$ ) or dilutions of affinity-purified antibodies overnight on a rocker platform.

Supernatants or purified antibodies were then removed from the wells. The nitrocellulose sheet was removed from the blotter and rinsed twice in DW. The blots were washed (three times for 5 min each in blotto) and then in PBS/0.5\% Tween 20. The blot was shaken 2 $\mathrm{hr}$ at room temperature in alkaline phosphatase conjugated or horseradish peroxidase-conjugated second-step antibody (Sigma or Vector Labs) at $1 / 1,000$ in PBS/ Tween for $2 \mathrm{hr}$, followed by two washes in DW and three 5-min washes in PBS/Tween. The protocol followed for use of alkaline phosphatase-conjugated antibodies was that of Blake et al. (1984). Blots were incubated in veronal acetate buffer $(0.075 \mathrm{M}$ barbital, $0.075 \mathrm{M}$ sodium acetate, $\mathrm{pH} \mathrm{9.6)}$ for $5 \mathrm{~min}$ at room temperature and then in color development solution $(0.1$ $\mathrm{ml}$ of $5 \mathrm{mg} / \mathrm{ml} \mathrm{5-bromo-4-chloroindolyl} \mathrm{phosphate} \mathrm{in}$ dimethylformamide $/ 1 \mathrm{ml} 1.0 \mathrm{mg} / \mathrm{ml}$ nitroblue tetrazolium in veronal acetate buffer $/ 0.02 \mathrm{ml} 2 \mathrm{M} \mathrm{Mg} \mathrm{Cl}_{2} / 9 \mathrm{ml}$ veronal acetate buffer) at $37^{\circ} \mathrm{C}$ for $1-3 \mathrm{hr}$. All chemicals were from Sigma. If a second-step horseradish peroxidase-conjugated antibody was used to reveal the bands, they were sometimes subsequently enhanced by the application of a tertiary peroxidase-conjugated antiperoxidase antibody (PAP) (Vector) prior to the application of substrate. The PAP kit from Vector was used according to manufacturers' instructions.

The blots were washed in DW three to five times and dried. To reveal additional proteins that did not stain with antibody, the blots were subsequently incubated in Aurodye (Janssen) in sealed plastic baggies with constant 


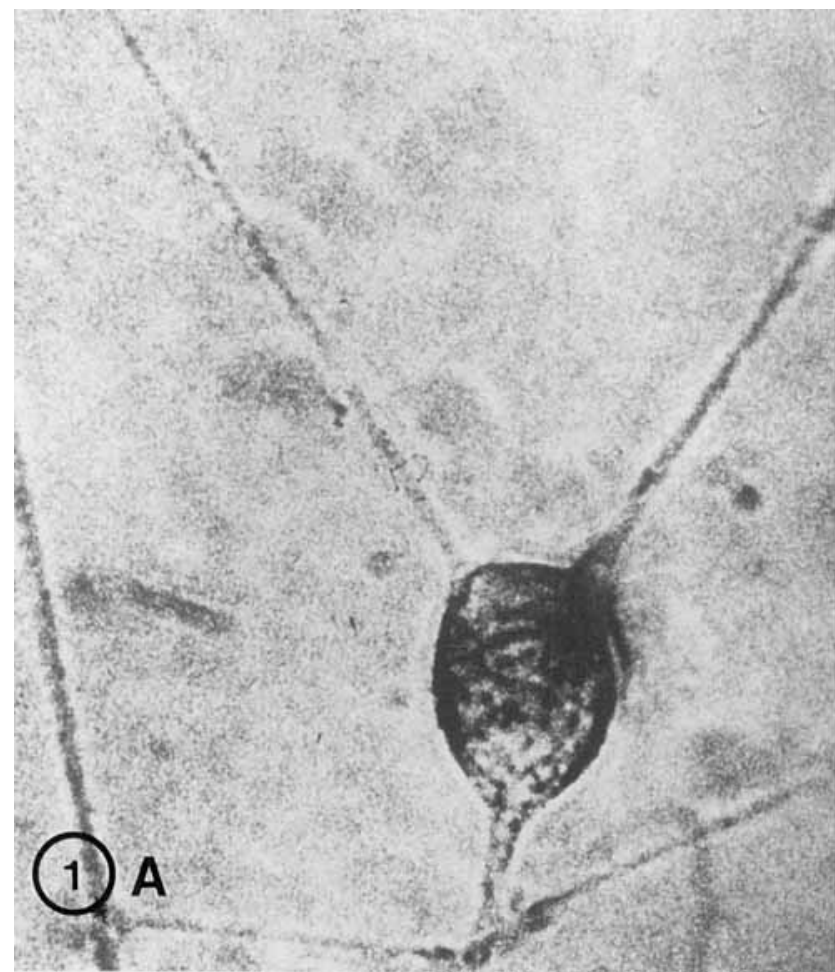

Fig. 1. Bright field (A) and fluorescence (B) micrographs of cultured 8-day embryonic chick ciliary ganglion neuron (cell body is $25 \mu \mathrm{m}$ in diameter) labeled with Mab CG-1 $(10 \mu \mathrm{g} / \mathrm{ml})$ and a second-step goat antimouse anti-IgG antibody (Miles; dilution 1/100) conjugated with rhodamine. Each of the antibodies was applied for $1 \mathrm{hr}$ to live cell cultures that were

agitation on a rocker platform shaker for $1-4 \mathrm{hr}(0.2 \mathrm{ml}$ AuroDye $/ \mathrm{cm}^{2}$ of membrane). The blot was then briefly washed in DW and air-dried. Blots were scanned with a Biomed Instruments Soft Laser Densitometer after making the nitrocellulose blot translucent by soaking $5 \mathrm{~min}$ in mineral cil.

\section{Affinity Purification of Mabs}

Mabs were purified from ascites fluid by the method of Bruck et al. (1982) by DEAE Affi-gel blue (Bio-Rad) chromatography. Both CG-1 and CG-4 are of the IgG $\gamma_{2 \mathrm{a}}$ subclass and CG-14 is of the IgG $\gamma_{3}$ as determined by a mouse Mab typing kit from Miles (now ICN). For purification of the antibodies, all steps were performed at $4^{\circ} \mathrm{C}$ or on ice. Ascites fluid was centrifuged at $100 \mathrm{~g}$ for $5 \mathrm{~min}$ to remove cells and then at $100,000 \mathrm{~g}$ for 30 min in a Beckman L4 ultracentrifuge to remove debris and fibrin clots.

The ascites fluid was dialyzed vs. 100 vol (between

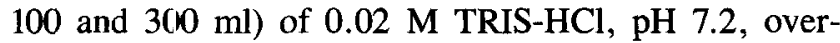
night. The dialysate was then centrifuged at $10,000 \mathrm{~g}$ for 10 min. A disposable Bio-Rad Econo-column was packed with $7 \mathrm{ml}$ DEAE Affi-gel blue (Bio-Rad 153-7307). One

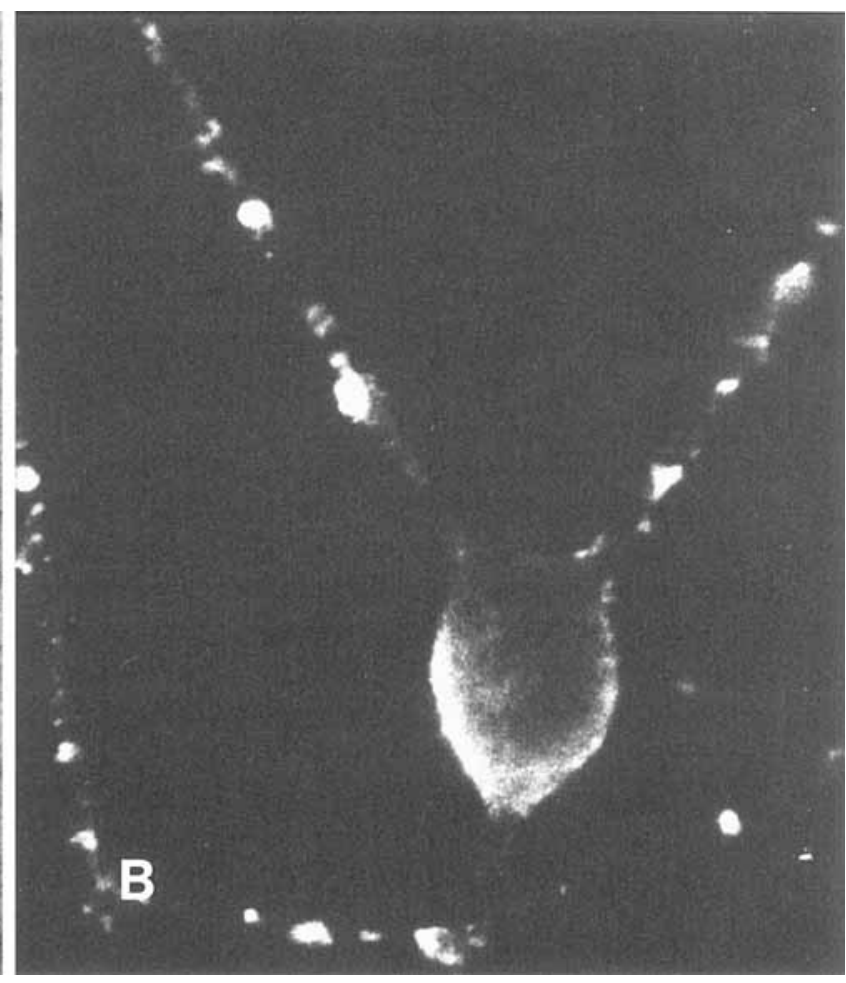

subsequently fixed with $2 \%$ paraformaldehyde in phosphatebuffered saline. Cultures were washed three times in phosphate-buffered saline between antibody treatments. The cell surface is labeled but there is no evidence of internal labeling. Punctate staining along the processes appears random.

milliliter of dialyzed ascites fluid was applied to the column, and the column was washed with 3 bed vol of the TRIS- $\mathrm{HCl}$ buffer, $\mathrm{pH}$ 7.2. The IgG fractions were eluted with a $200 \mathrm{ml} \mathrm{0-100} \mathrm{mM} \mathrm{NaCl}$ gradient. The flow rate was $30-50 \mathrm{ml} / \mathrm{hr} ; 1-\mathrm{ml}$ fractions were collected on a Foxy (ISCO) programmable fraction collector. The immunoglobulin fractions were pooled and could be stored at $4{ }^{\circ} \mathrm{C}$ on ice in $0.02 \% \mathrm{NaN}_{3}$. None of the antibodies can be successfully frozen. The column was regenerated by washing with 3 bed vol $6 \mathrm{M}$ guanidine $\mathrm{HCl}, 10$ bed vol of $0.5 \mathrm{M} \mathrm{NaCl}$, and 5 bed vol of $0.02 \mathrm{M}$ TRIS-HCl, $\mathrm{pH} 7.2$.

\section{Cytotoxicity Assays}

Cytotoxicity of the Mabs to CG neurons or to NC cells was determined by measuring the percentage of specific cytotoxicity of the CG neurons labeled with Mabs CG-1, CG-4, and CG-14 alone and in various ratios in the presence of guinea pig complement (Miles [now ICN]). Percentage of specific cytotoxicity was defined as $[(\%$ dead cells experimental - \% dead cells control $) / 100 \%$ $-\%$ dead cells control] $\times 100$. Complement was reconstituted according to the manufacturers' instructions (which 

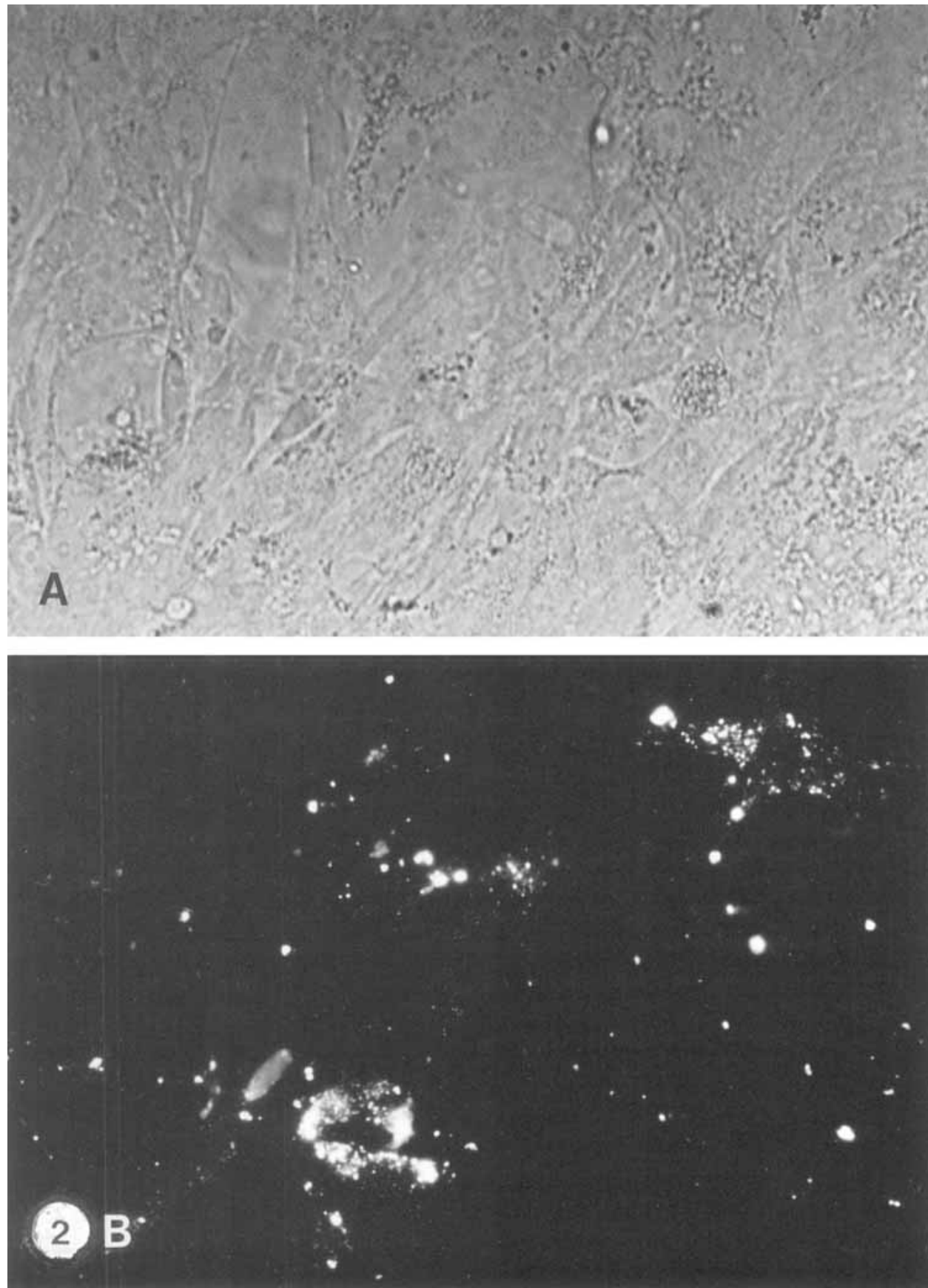

Fig. 2. NC cells from a 31-hr chick embryo (mesencephalic region) were explanted into culture with the neural tube, which was removed after $8 \mathrm{hr}$ in culture. NC cells were allowed to grow out onto polyornithine-collagen-coated coverslips. Cells had been in culture for 3 days when the phase-contrast micrograph in A was made. $\mathbf{B}$ is the same field as in A shown in a

differed for each batch), aliquoted, and stored frozen at $-20^{\circ} \mathrm{C}$ until use. The neuronal or NC cells were incubated for $15 \mathrm{~min}$ in serum-free medium buffered with 5 $\mathrm{mM}$ HEPES, and then guinea pig complement in varying dilutions was added. fluorescence micrograph of cells made after treatment with Mab CG-1 conjugated with biotin. Cells stain brightly with rhodamine-linked avidin after the biotin antibody step. The antibody stains about $5 \%$ of the mesencephalic NC cells in culture, and such cells are often found in close proximity to one another as in this micrograph.

Cell lysis was determined by staining the cell preparations with ethidium bromide and acridine orange (1 part per million each) (Parks et al., 1979) and counting as detailed above. Live cells were green and dead cells orange when viewed with a Leitz Diavert microscope 
equipped with epifluorescence at the appropriate wavelength for fluorescein.

\section{RESULTS}

The experiments described here were designed 1) to determine whether the antigen(s) recognized by Mab CG-14, made to mesencephalic neural crest cells, and which also labeled CG neurons, was the same as that recognized by the previously characterized Mabs (CG-1 and CG-4) we had made to CG neurons and 2) to characterize the antigen(s) further.

\section{Antibody Distribution}

CG-1 and CG-4. The distribution of both CG-1 and CG-4 Mabs was uniform on the surface of cell bodies of CG neurons, as previously reported (Barald, 1982), although there was some punctate staining along the neurites (Fig. 1). At the level of light microscopy it was difficult to determine whether this appearance reflected surface features of neuronal processes such as varicosities or whether scattered patches of antigen produced this distribution of fluorescence. The punctate staining was similar to that observed on the same neurons with a monoclonal antiacetylcholinesterase (anti-AChE) antibody (Barald, et al. unpublished results; data not shown).

The antibodies made by clones CG- 1 and CG-4 also could be used to identify a small ( $\leqslant 5 \%)$ subpopulation of mesencephalic NC cells from stage 9 chick embryos ( 31 hr in ovo) in culture. These cells could be identified as soon as explanted crest attached to culture plates in vitro (within $2 \mathrm{hr}$ ). Antibody conjugated to biotin and reacted with rhodamine-avidin could be seen in a nonuniform distribution over the surface of the subpopulation of cultured mesencephalic crest cells (Fig. 2). Testing of the NC cells' reactivity with CG-1 or CG4 began within hours after NC cells were placed in culture and was performed on cultures for up to 2.5 weeks of incubation. The same proportion of the cells (5\%) labeled at these times if cells were kept under conditions that promoted proliferation (see below). Explanted trunk NC cells from stage 11 to stage 17 embryos derived and cultured in the same manner as the mesencephalic crest never stained in vitro with either the CG-1 or the CG-4 antibody. We have also identified these cells in cryosectioned material from embryos prepared as early as $31 \mathrm{hr}$ after placement of fertilized eggs in the incubator (data not shown: Barald and Wolff, manuscript in prepa-

Fig. 3. Monoclonal antibody CG-14 stains embryonic day 8 CG neurons $(\mathbf{A}, \mathbf{B})$ and 31-hr mesencephalic NC cells $(\mathbf{C}, \mathbf{D})$ in culture after $24 \mathrm{hr}$. Methods are as in Figures 1 and 2. Distribution of the CG-14 antibodies on NC and CG cells resembles that seen for CG-1 and CG-4. Bars $=10 \mu \mathrm{m}$. Arrows in (C) indicate the two cells seen at higher magnification in (D).
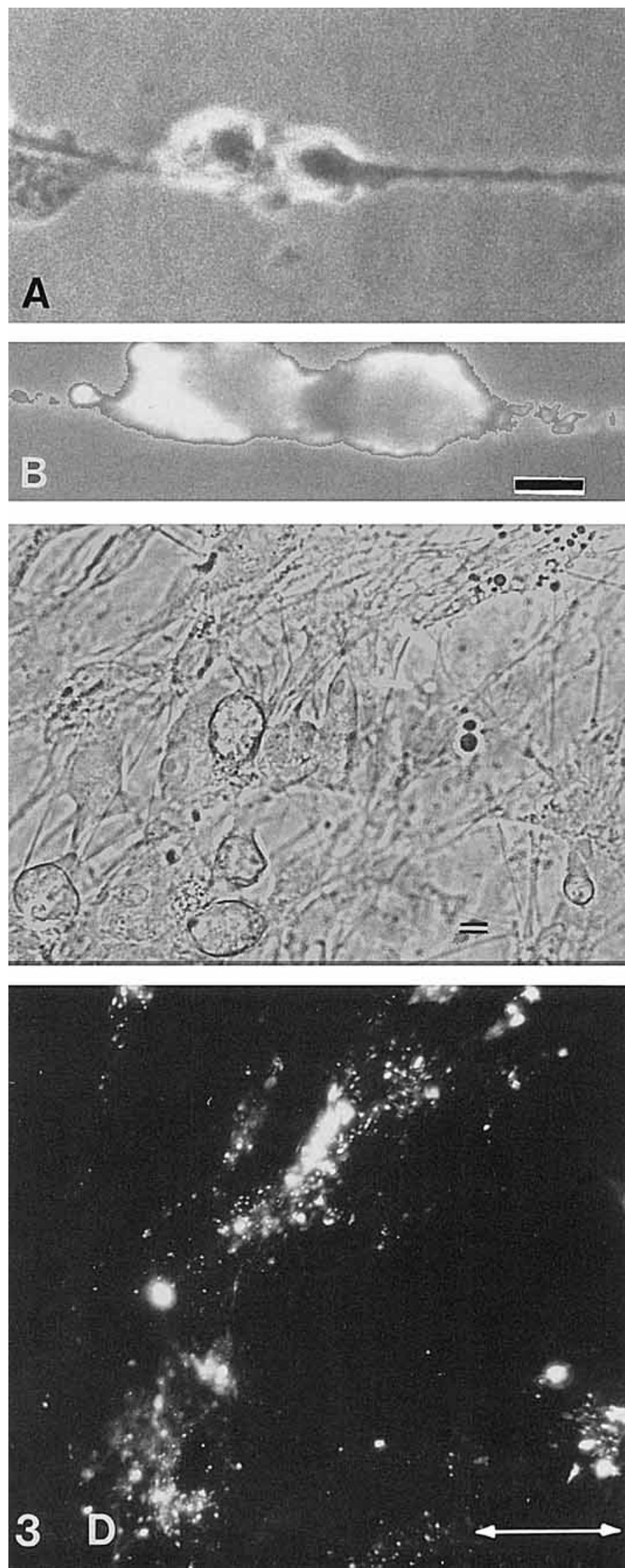
ration). Also, staining of cryostat sections of 29 somite embryos revealed staining of a few truncal NC cells posterior to somite pair 28 ; no more than 25 cells were stained in any embryo (data not shown; Barald and Wolff, manuscript in preparation).

CG-14, the Mab made to nitrocellulose-bound NC cells, also labeled both the subpopulation of NC cells in cell cultures and CG neurons at identical times (Fig. 3; Barald and Wolff, manuscript in preparation).

\section{The Relationship of CG-14 to CG-1 and CG-4}

Blocking studies. Blocking studies were conducted to determine the ability of various reagents to block binding of the specific Mabs and vice versa (Table I). The binding of either CG-1 or CG-4 or (CG-1 plus CG4) blocked the binding of CG-14, and CG-14 blocked the binding of either CG-1 or CG- 4 or both together to the CG neurons and NC cells. Unlabeled antibodies CG-1, CG-4, and CG-14 blocked the binding of their own forms of biotin-conjugated IgG, revealed with fluorescent avidin-D, as well. In qualitative studies with fluorescent antibodies, CG-4 did not block the binding of CG-1 and CG-1 did not block the binding of CG-4 to either cryostat-sectioned embryos or cultured CG and NC cells. Quantitative studies with two different radioligands are presently underway, however. When the AChE Mabs were applied with appropriate fluorescent second-step antibodies, each CG Mab was capable of binding to the cell surface, and it could be visualized with a second-step antibody and a different fluorochrome (data not shown). $\alpha$-Bungarotoxin (BTX) binding to CG neurons also did not block the binding of any of the three Mabs tested, nor did Mab binding block BTX binding.

Cytotoxicity of Mabs. Antibodies CG-1 and CG-4 were synergistically cytotoxic (in ratios of $8: 1$ ) for both CG neurons and NC cells that were labeled in culture (initially reported by Barald [1982]). This occurred only in the presence of added complement (see Fig. 4). The CG-1 and CG-4 Mabs are of the IgG $\gamma_{2 \mathrm{a}}$ class, as determined with an antibody subtyping kit from Miles Yeda (now ICN).

Five micrograms of affinity-purified CG-1 and 0.6 $\mu \mathrm{g}$ of CG-4 in $1 \mathrm{ml}$ of culture medium kill the neurons or NC cells within 15-30 min after the addition of guinea pig or rabbit complement. Ninety-five percent of the cultured CG neurons were killed under similar conditions; the cells retracted their neurites, cytolysed, and were released from the culture dish (Fig. 4) [Barald, 1982]. Neither antibody alone was cytotoxic for either CG or NC cells. In the absence of complement or if complement was heat inactivated, neuronal cells were able to extend long neurites even in the presence of high concentrations of CG-1 or CG-4 antibody, singly or together. NC cells were able to multiply in the presence of the antibodies, with division times similar to those of

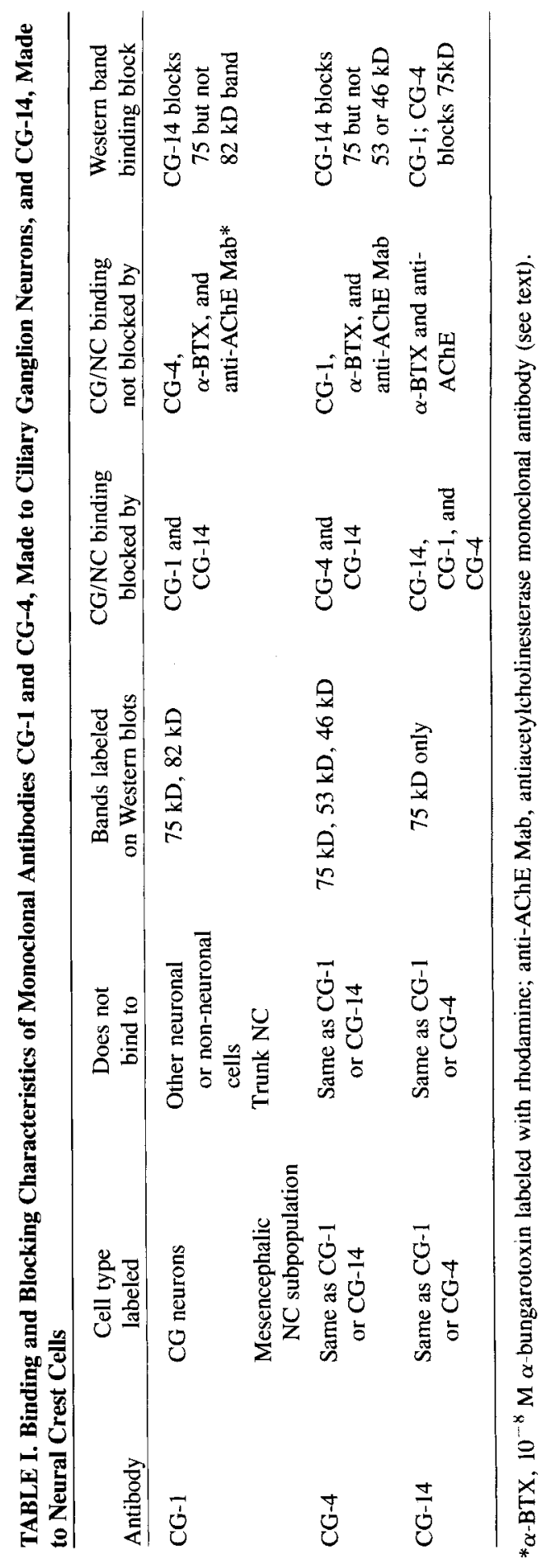




\section{Complement-Mediated Cytoxicity}

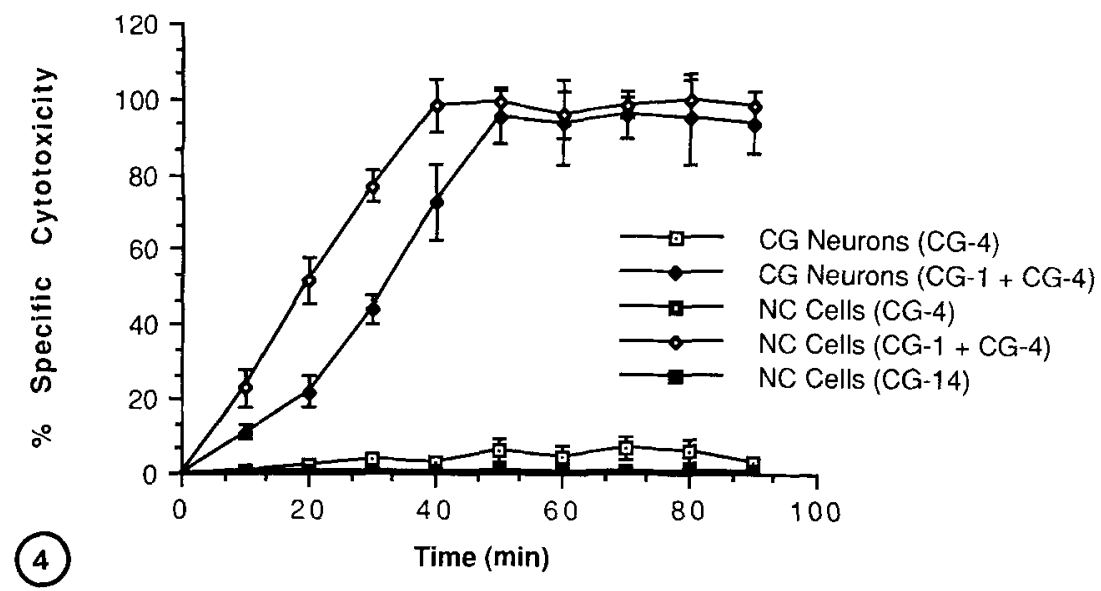

Fig. 4. The percentage of specific cytotoxicity of $\mathrm{CG}$ neurons and NC cells labeled with Mab CG-4 alone or Mab CG-14 alone and Mabs CG-1 and CG-4 in ratios of 8:1(CG-1 + CG4 ) in the presence of guinea pig complement. Mab CG-14 is not cytotoxic in company with either or both of the other antibodies (data not shown). Neither Mab CG-1 nor CG-4 alone kills the $\mathrm{CG}$ neurons or NC cells in any great numbers even after $80 \mathrm{~min}$ incubation (data shown for CG-4). Use of CG-1 and CG-4 together kills $95 \%$ of the CG neurons in less than $60 \mathrm{~min}$; all NC cells die within $40 \mathrm{~min}$. The $\mathrm{CG}$ neurons are obtained from 8-day embryonic chick, cultured for 3 days and then treated with $5 \mu \mathrm{g} / \mathrm{ml}$ of CG-4 (affinity-purified IgG).

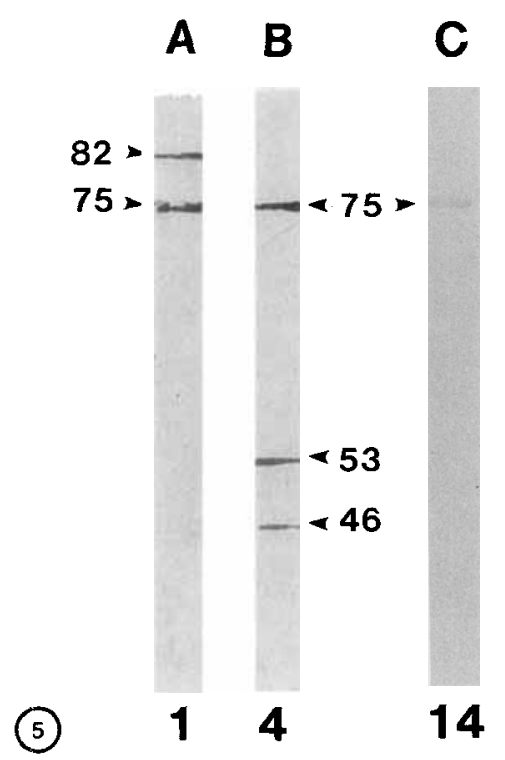

Fig. 5. Affinity-purified monoclonal antibodies CG-1 (A), CG-4 (B), and CG-14 (C) were used to stain Western blots of polypeptides separated on denaturing SDS polyacrylamide gels (see Materials and Methods). The bands in A and B were enhanced both by overloading the gel and by the peroxidaseantiperoxidase technique (see Materials and Methods). That in $\mathrm{C}$ was not enhanced prior to the application of substrate, and the gel was not overloaded. Note that all three Mabs stain the same $75 \mathrm{kD}$ band, but that additional bands are stained in A and B. In overloaded gels of either NC or CG neurons, only the $75 \mathrm{kD}$ band stains with CG-14 (data not shown).
$\mathrm{NC}$ cells are lysed after $2 \mathrm{hr}$ in culture (after being removed from a 31-hr embryo). Here the cells were tested after 4 days in culture. (They can be lysed from the time they are placed in culture at $31 \mathrm{hr}$ after fertilization to a time 3 weeks later, the last time tested.) In the experiments in which the Mabs were used together (CG-1 + CG-4), $5 \mu \mathrm{g} / \mathrm{ml}$ of CG-1 and $0.63 \mu \mathrm{g} / \mathrm{ml}$ of $\mathrm{CG}-4$ were used. The cells were incubated for $15 \mathrm{~min}$ and then guinea pig complement was added. Cell lysis was determined by the ethidium bromide acridine orange method and is expressed as the percentage of specific cytotoxicity (Parks et al., 1979).

cultures to which no antibody was added (see Barald, 1988) if complement was not present.

In crest cultures that had been treated with antibodies and complement, no additional cells bearing antibodybinding sites appeared; no cells were stained subsequently with the antibodies even up to 2.5 weeks later. The remaining cranial NC cells were unaffected by the presence of the antibodies and complement. They continued to divide and remained viable for many weeks after treatment. Trunk crest and other neuronal and non-neuronal cells tested were unaffected by the antibodies in the presence or absence of complement.

CG-14 did not have cytotoxic properties when used alone or in company with CG-1 or CG-4. When added at the same time as CG-1 and CG-4 it had no effect on cytotoxicity. However, if CG-14 were allowed to bind to cultures of $\mathrm{CG}$ or $\mathrm{NC}$ cells prior to the addition of CG-1 and $\mathrm{CG}-4$ in ratios that usually resulted in cell lysis, only limited cytotoxicity (for CG, $10 \pm 3 \%$ S.E.M., $N=6$; for NC, $5 \pm 2 \%$ S.E.M., $N=4$ ) was observed over the time when the effect of CG-1 and CG-4 was usually maximal (95 $\pm 3 \%$ of $C G$ cells killed; elimination of all NC cells).

\section{Western Blots}

We have identified the peptides that all three antibodies label (Fig. 5). CG neurons or NC cell peptides were separated by one-dimensional polyacrylamide gel electrophoresis and the antigens identified on Western transfers to nitrocellulose paper (Towbin et al., 1979) in 
deliberately overloaded gels. Such deliberate overloading is illustrated in Figure 5A,B. Mab CG-1 labels a band at 75 and one at $82 \mathrm{kD}$. Mab CG-4 labels the 75 but not the $82 \mathrm{kD}$ band as well as two other bands of 53 and $46 \mathrm{kD}$ in both CG and NC cells. Mab CG-14 labels the $75 \mathrm{kD}$ band only (Fig. 5). Overloading of the gels did not bring out binding to additional bands in any of the blots, indicating that underloading is not the explanation for our not seeing any minor bands, and, for example, the CG-1 Mab not labeling the bands of smaller molecular weight recognized by CG-4. CG-14 blocked the binding of either CG-1 or CG-4 to the $75 \mathrm{kD}$ band but not to any of the other bands on the Western blots. CG-1 and/or CG-4 blocked the binding of CG-14 to the $75 \mathrm{kD}$ band. The relationship of the 82,53 , and $46 \mathrm{kD}$ bands to the $75 \mathrm{kD}$ band and the relationship between the antigen(s) and epitope(s) recognized by all three Mabs are presently under investigation.

\section{DISCUSSION}

\section{Mabs Made to CG Neurons and Mesencephalic NC Cells Recognize the Same Antigen}

The CG-1 and CG-4 Mabs were among the first markers for a specific population of neurons and for a specific subpopulation of neural crest cells (Barald, 1982). We have now been able to isolate a third Mab, called CG-14, which was made not to CG neurons but to mesencephalic NC cells (Barald, 1988; Barald and Wolff, manuscript in preparation). The labeled antigen(s) seen by all three antibodies appear to be common to the CG neurons' cell surface and to the cell surface of a subpopulation of $\mathrm{NC}$ cells.

CG-14 is another highly specific monoclonal antibody that identifies a neural crest subpopulation; others have been previously reported (Barald, 1982, 1987; Barald and Wessells, 1984; Ciment and Weston, 1983; Duband et al., 1985; Barbu et al., 1986; Weston et al., 1988). This finding adds another piece of supporting evidence for the hypotheses that 1) neural crest is a heterogeneous collection of cells, at least some of which are determined early in ontogeny (Barald, 1982; for review, see LeDouarin, 1986a,b; Weston et al., 1988); and 2) neuronal precursors with some of the traits of the neurons they may eventually become can be found in NC cells in embryos in which crest migration has just begun or is yet to begin.

\section{Mab CG-14 Blocks the Binding of CG-1 and/or CG-4 to Cells and Western Blots}

We have shown by binding and blocking studies on live CG and NC cells that CG-14 blocks the binding of Mabs CG-1 and CG-4 but not BTX-binding sites or AChE monoclonal antibodies (Table I) (see also Barald,
1988). In Western blots of isolated electrophoresed polypeptides, CG-14 labels the $75 \mathrm{kD}$ polypeptide, which is the only one of the four polypeptides recognized by either CG-1 or CG-4. This $75 \mathrm{kD}$ band is recognized in common by all three Mabs on Western blots. Further, CG-14 blocks the binding of CG-1 and CG-4 to the $75 \mathrm{kD}$ band, but not to the other bands (see below). Quantitative studies using antibodies labeled with two different isotopes are presently being used to determine whether the qualitative studies done with fluorescently labeled material can be confirmed. Quantitation of fluorescently labeled probes is notoriously difficult. Endoglycosidase F digestion of surface membranes isolated from both $\mathrm{CG}$ neurons and NC cells does not interfere with binding to Western blots (Barald and Wolff, manuscript in preparation).

Therefore we believe from the data presented here, as well as from the endo $F$ studies, that the epitopes recognized by these Mabs are protein and not carbohydrate moieties. We deliberately used NC cells to produce a monoclonal antibody to the same antigen(s) recognized by CG-1 and CG-4; however, the search necessitated screening 20 separate fusions for what proved to be a single antibody. Over 30,000 clones per fusion were raised and tested, but we do not know how many of these were duplicates. The fact that we have hit upon the same antigen by screening antibodies made to both $\mathrm{NC}$ and $\mathrm{CG}$ cells probably indicates that the antigen is both abundant and a "good" antigen in the immunological sense, and it is probably important for cell function (see Barald, 1988). We can now use these antibodies to clone the gene(s) for the proteins recognized by these Mabs, and this is underway.

\section{The Question of “Jumping” Antigenic Determinants: What Are the Labeled Epitopes?}

Because monoclonal antibodies bind to so called "jumping antigenic determinants," unrelated epitopes that are fortuitously present in labeled cells (for discussion, see Barald, 1987) we must now establish the relationship between the $82,53,46$, and $75 \mathrm{kD}$ polypeptides labeled by the Mabs on Western blots. It is possible that one or all of the bands on CG neurons or NC cells unique to Mab CG-1 or CG-4 represent jumping antigenic determinants, epitopes unrelated to the $75 \mathrm{kD}$ antigen band, which are fortuitously labeled by the antibodies. However, since the same bands are recognized on both $\mathrm{CG}$ neurons and NC cells by each antibody, this is probably unlikely. Furthermore, Western blots of other tissues from chick, including brain, dorsal root ganglion, the sympathetic chain, the adrenal medulla, the gut, liver, heart, eyes, and notochord are never labeled (Barald, 1982; Barald, unpublished data). If the 82, 53, and 46 $\mathrm{kD}$ bands represent jumping antigenic determinants, one 
would expect to find them in other avian tissues. In an attempt to link epitopes recognized by CG-1 and CG-4, cross-linking studies are being undertaken to define the exact relationship of the antigens labeled by CG-1 and CG-4. If the two antibodies recognize different, widely spaced epitopes on a single molecule, this could explain the failure of CG- 1 to block the binding of CG-4 and vice versa. Because of the synergistic complement-mediated cytotoxicity, the epitopes, if not on the same molecule, are probably closely associated on the cell surface.

\section{What is the Relationship Between the NC Subpopulation and the Ciliary Ganglion?}

It will be important to establish the relationship of the labeled neural crest subpopulation to the ciliary ganglion. To determine whether the NC cells that label with the Mabs are in fact precursors of neuronal cells in the ciliary ganglion, it will be important to trace the lineages of these cells in the embryo during development.

The results of our experiments show that antigenpositive cells in the cultures are ablated by antibodies CG-1 and CG-4 (in specific ratios) and complement. After such ablation, no cells arise in the cultures that can be labeled with any of the three Mabs during the subsequent 2-3 weeks. This result may give us a tool with which to affect embryonic development both in vivo and in vitro (see also Barald, 1988).

The initial characterization of CG-14 and its origin strengthen our hypothesis that the NC subpopulation recognized by Mabs CG-14, CG-1, and CG-4 may contain precursors of the $\mathrm{CG}$ neurons that have segregated from the mesencephalic NC early in development.

\section{ACKNOW'LEDGMENTS}

This work was supported by grant PCM 17271 from the National Science Foundation to K.F.B. and by USPHS grants NS17262 and NS17017 to K.F.B. K.F.B. was also the recipient of grants from the Muscular Dystrophy Association of America and the Dysautonomia Foundation and a Faculty Recognition Award from the University of Michigan. The author thanks Laurie Polacek, Tami Hill, Dagmar Wolff, and Cindy Lam for excellent technical assistance and Kathryn Tosney, Carol Erickson, Gary Ciment, James Weston, Mike Marusich, Drew Noden, and Gerry Maxwell for many helpful and enjoyable discussions during the course of this work.

\section{REFERENCES}

Anderson D., Stein R, Axel R (1985): Gene expression in differentiating and transdifferentiating neural crest cells. Cold Spring Harbor Symp Quant Biol 50:855-863.

Anderson DJ, A.xel RA (1986): Bipotential neuroendocrine precursor whose choice of cell fate is determined by NGF and glucocorticoids. Cell 47:1079-1090.
Barald KF (1981): Cell surface specific monoclonal antibodies to chick ciliary ganglion neurons. Soc Neurosci Abstr 7:129.

Barald KF (1982): Monoclonal antibodies to embryonic neurons: Cell-specific markers for chick ciliary ganglion. In Spitzer NC (ed): "Neuronal Development." New York: Plenum, pp 101119 .

Barald KF (1987): Purification of antigen-specific B cells by adherence to whole cell antigens. In Pretlow TG, Pretlow TP (eds): "Cell Separation: Methods and Selected Applications," Vol. 5. San Diego: Academic Press, Inc., pp 98-102.

Barald KF (1988): The antigen recognized by monoclonal antibodies to mesencephalic neural crest and to ciliary ganglion neurons is involved in the high affinity choline uptake mechanism in these cells. J Neurosci Res (in press).

Barald KF, Berg DK (1979): Ciliary ganglion neurons in cell culture: High affinity choline uptake and autoradiographic choline labeling. Dev Biol 72:15-23.

Barald KF, Wessells NK (1984): Differential antigen adhesivity used to select spleen cells for the production of monoclonal antibodies to embryonic neurons. J Immunol Methods 73:1-15.

Barbu M, Ziller C, Rong PM, LeDourain NM (1986): Heterogeneity in migrating neural crest cells revealed by a monoclonal antibody. J Neurosci 6:2215-2225.

Blake MS, Johnston KH, Russell-Jones GJ, Gotschlich EC (1984): A rapid sensitive method for detection of alkaline phosphataseconjugated antibody on Western blots. Anal Biochem 136:175179.

Bruck C, Portetelle D, Glineur C, Bollen A (1982): One-step purification of mouse monoclonal antibodies from ascitic fluid by DEAE affi-gel blue chromatography. J Immunol Methods 53:313-319.

Ciment G, Weston JA (1982): Early appearance in neural crest and crest-derived cells of an antigenic determinant present in avian neurons. Dev Biol 93:355-367.

Ciment G, Weston JA (1983): Enteric neurogenesis by neural crestderived branchial arch mesenchymal cells. Nature (Lond) 305:424-427.

Ciment G, Weston JA (1985): Segregation of developmental abilities in neural-crest derived cells: Identification of partially restricted intermediate cell types in the branchial arches of avian embryos. Dev Biol 111:73-83.

Duband J-L, Tucker GC, Poole TJ, Vincent M, Aoyama H, Thiery J$P$ (1985): How do the migratory and adhesive properties of the neural crest govern ganglia formation in the avian peripheral nervous system? J Cell Biochem 27:189-203.

Hamburger V, Hamilton HL (1951): A series of normal stages in the development of the chick embryo. J Morphol 88:49-92.

Laemmli UK (1970): Cleavage of structural proteins during the assembly of the head of bacteriophage T4. Nature (Lond) 227:680-685.

Landmesser L, Pilar G (1972): The onset and development of transmission in the chick ciliary ganglion. J Physiol 222:691-713.

LeDouarin NM (1983): “The Neural Crest." London: Cambridge University Press

LeDouarin NM (1986a): Cell line segregation during peripheral nervous system ontogeny. Science 231:1515-1522.

LeDouarin NM (1986b): Investigations on the neural crest. Methodological aspects and recent advances. Ann NY Acad Sci 486:66-86.

LeDouarin NM, Teillet MA, Ziller C, Smith J (1978): Adrenergic differentiation of cells of the cholinergic ciliary and Remak ganglia in avian embryo after in vivo transplantation. Proc Natl Acad Sci USA 75:2030-2034.

LeDouarin NM, Xue ZG, Smith J (1985): In vivo and in vitro studies on the segregation of autonomic and sensory cell lineages. $\mathrm{J}$ Physiol (Paris) 80:255-261. 
Marusich MF, Pourmehr K, Weston JA (1986): Subpopulations of morphologically non-neuronal neural crest and dorsal root ganglion (DRG) cells express a sensory neuron specific epitope. Prog Clin Biol Res 217B:249-253.

Narayanan CH, Narayanan Y (1978): On the origin of the ciliary ganglion in birds studied by the method of interspecific transplantation of embryonic brain regions between quail and chick. J Embryol Exp Morphol 47:137-148.

Nishi R, Berg DK (1977): Dissociated ciliary ganglion neurons in vitro: Survival and synapse formation. Proc Natl Acad Sci USA 74:5171-5175.

Nishi R, Berg DK (1981a): Effects of high $\mathrm{K}^{+}$concentrations on the growth and development of ciliary ganglion neurons in cell culture. Dev Biol 87:301-307.

Nishi R, Berg DK (1981b): Two components from eye tissue that differentially stimulate the growth and development of ciliary ganglion neurons in cell culture. J Neurosci 1:505-513.

Noden DM (1978): The control of avian cephalic neural crest cytodifferentiation. II: Neural tissues. Dev Biol 67:313-329.

Parks DR, Bryan VM, Oi VT, Herzenberg LA (1979): Antigenspecific identification and cloning of hybridomas with a fluorescence-activated cell sorter. Proc Natl Acad Sci USA 76:1962-1971.

Sieber-Blum M, Cohen AM (1980): Clonal analysis of quail neural crest cells. They are pluripotent and differentiate in vitro in the absence of noncrest cells. Dev Biol 80:96-106.
Skaper SD, Selak I,'Manthorpe M, Varon S (1984): Chemically defined requirements for the survival of cultured 8-day chick embryo ciliary ganglion neurons. Brain Res 302:281-290.

Smith J, Fauquet M, Ziller C, LeDouarin NM (1979): Acetylcholine synthesis by mesencephalic neural crest cells in the process of migration in vivo. Nature (Lond) 282:853-855.

Towbin H, Staehelin T, Gordon J (1979): Electrophoretic transfer of proteins from polyacrylamide gels to nitrocellulose sheets: Procedure and some applications. Proc Natl Acad Sci USA 76:4350-4355

Vincent M, Duband J-L, Thiery J-P (1983): A cell surface determinant expressed early on migrating avian neural crest cells. Dev Brain Res 9:235-238.

Weston JA (1983): Regulation of neural crest cell migration and differentiation. In Yamada KM (ed): Cell Interactions and Development: Molecular Mechanisms. New York: John Wiley \& Sons, pp 153-184.

Weston JA, Vogel KS, Marusich MF (1988): Identification and fate of neural crest cell subpopulations in early embryonic development. In Easter SS, Barald KF, Carlson BM (eds): "Message To Mind: Directions in Developmental Neurobiology." Sunderland, MA: Sinauer, pp 224-237.

Ziller C, Fauquet M, Kalcheim C, Smith J, LeDouarin NM (1987): Cell lineages in peripheral nervous system ontogeny: Mediuminduced modulation of neuronal phenotypic expression in neural crest cell culture. Dev Biol 120:101-111. 